\title{
Vloga moških oblačil $v$ jaromeščanskem ambientu Kersnikovih romanov Ciklamen in Agitator
}

\author{
ANA PEROVIĆ \\ Univerza v Mariboru, Filozofska fakulteta, Koroška cesta 160, \\ SI-2000 Maribor, ana.peroviceva@gmail.com
}

\begin{abstract}
V članku so predstavljeni moški oblačilni videzi, kakor se pojavljajo v Kersnikovih romanih Ciklamen in Agitator. Proučujem jih kot dele slovenskega jaromeščanskega ambienta. Kot taka se oblačila pokažejo v funkciji prikazovanja še ne povsem razvitega meščanskega habitusa slovenskih pokrajin v drugi polovici 19. stoletja, medrazredno in znotrajrazredno razlikovanje s pomočjo oblačil je v funkciji komičnega, različni oblačilni videzi pa sugerirajo osebnostne lastnosti posameznikov.
\end{abstract}

In this paper we consider men's clothing designs as they are depicted in Kersnik's novels Ciklamen and Agitator. We analyse them as part of the Slovene petit bourgeois ambience. As such, the clothes serve the function of portraying the relative underdevelopment of Slovene provinces in the second part of the $19^{\text {th }}$ century. The interclass and intraclass differentiation indicated through clothing is used in a comical function and different clothing designs suggest personality features of individuals.

Ključne besede: Janko Kersnik, meščanstvo, Ciklamen, Agitator, moška oblačila

Key words: Janko Kersnik, bourgeoisie, Ciklamen, Agitator, men's clothing

\section{Uvod}

Analizirala bom oblačila moških literarnih likov v Kersnikovih romanih Ciklamen in Agitator. Za moška oblačila se odločam, ker me zanima, kako pisatelj s pomočjo moške oblačilne kulture prikazuje slovensko meščansko identiteto. 
Moška obleka se je v razvoju oblačilne kulture sicer manj spreminjala kot ženska, kar pa ne pomeni, da moški modi niso sledili. Prav v času Kersnikovih romanov sta postali moška obleka in moda nasploh dostopni širšemu krogu ljudi, ki so z razvojem slovenskih trgov in mest dobili tudi priložnosti za nošenje svečanih oblek. Raziskava je zanimiva tudi zato, ker v Kersnikovem jaromeščanskem uradniku prepoznavamo predhodnike Cankarjevih filistrov.

Najprej bom preučila namembnost in morfološke značilnosti posameznih oblačilnih kosov ter njihovo mesto v razvoju oblačilne kulture, kar se povezuje tudi z zgodovinskim in sociološkim kontekstom posameznega obdobja. Analizirala bom motivno-tematske sklope, v katerih se oblačilo pojavlja. Preučila bom, če se oblačila pojavljajo kot literarni simboli. ${ }^{1}$ Postavljam si vprašanje, kako se ohranja tradicionalna simbolika oblačila, kako se ta modificira ali povsem spreminja. Oblačilne kose lahko preučujem kot dele opisa literarnega lika ali kot sredstva karakterizacije, ki lahko prerašča $\mathrm{v}$ ironijo in satiro ter pomaga oblikovati karikature. Zanima me, kateri oblačilni kosi se najpogosteje pojavljajo, pri tem pa iščem razloge za njihovo pojavljanje.

Analiza oblačil in oblačilne kulture v kulturno-sociološkem pogledu, znotraj specifičnega časa in kraja, je veliko lažja od poskusa umeščanja posameznih oblačilnih kosov ali videzov, ki se v literarnem delu pojavljajo, v literarnoteoretske kategorije, katerih izhodišča so velikokrat kompleksnejša, večkrat izključujoča. Pri analizi Kersnikovih romanov se sklicujemo predvsem na oblačilno kulturo druge polovice 19. stoletja in na motivno-tematske sklope literarnega dela.

Izraz jaromeščanski iz naslova se nanaša na stopnjo razvitosti slovenskega meščanstva $\mathrm{v}$ drugi polovici 19. stoletja, ko pravzaprav govorimo o rojstvu pravega slovenskega meščanstva. To je bilo kot po drugih mestih habsburške monarhije nacionalno pisano, in sicer slovensko in nemško, slovensko in italijansko, slovensko in madžarsko. Pobudo za uveljavljanje narodnostnih pravic Slovencev so po letu 1848 prevzeli sloji slovenskih obrtnikov, trgovcev in izobražencev. Zgodil se je preobrat iz stanovske v meščansko kapitalistično družbeno ureditev, pot do meščanskega stanu pa je utirala tudi izobrazba. Pravega meščanstva je bilo po slovenskih mestih sicer malo ali naši meščani v glavnem niso dosegali standardov meščanskih sredin večjih evropskih središč (Žmuc 2008: 68-71). Omenjeno dejstvo je v obravnavanih romanih prikazano tudi s pomočjo opisovanja oblačilnih navad slovenskega meščanstva $v$ iskanju lastne identitete. Res je bil del Kersnikovih literarnih likov premožnejši in med njimi srečamo tudi izobražence. A obe sredini ob trški jari gospodi delujeta bolj kot izjemi, saj sta meščanske navade prinesli iz tujih evropskih mest. Večina prebivalcev kraja Borje se na novo modo in posnemanje meščanskega življenja šele navaja, nekaterim pa novih načinov oblačenja še ni bilo mogoče privzgojiti.

${ }^{1}$ Oblačilo je del zunanje, vidne podobe človeka, osebnost pa je tisto, kar opredeljujemo kot s čutili nezaznavno. Če oblačilo kot simbol združuje vidno z nevidnim, potem največkrat signalizira neko duševno, duhovno lastnost posameznika ali družbe. Enako v Slovarju simbolov trdi tudi Chevalier (1993: 392). 
Mnogi od njih so se sicer dokopali do denarnega blagostanja, kar jih motivira v posnemanju meščanov, a njihova želja po pripadnosti deluje komično. Pogačnik (1997: 29) piše o strukturi literarnih likov iz povesti Jara gospoda, ki je podobna likom v romanih Ciklamen in Agitator; da gre za ljudi, ki kmetstvu ne pripadajo več, meščani pa še niso postali, kar je povzročilo, da so izgubili svoj ambient. Tega na novo sooblikuje le nekaj pravih meščanskih posameznikov, ki so se oblačili meščansko. Kersnik piše recimo o muslinastih rokavicah, ki so gotovo znak meščanskosti. ${ }^{2}$ Prevladujoči sloj pa so vendarle predstavljali ljudje, ki so se zgolj želeli približati prebivalcem večjih mest. Opisi meščanske oblačilne kulture se v Kersnikovih romanih seveda pojavljajo, opazimo tudi prizadevanje za dvig posameznikov na družbeni lestvici, vendar so poskusi nastajajočega meščanstva največkrat tematizirani s humorne perspektive. $\mathrm{Ob}$ tem je treba poudariti, da med oblačilno kulturo slovenskega meščanstva in Kersnikovo tematizacijo le-te ne zapisujemo popolnega enačaja. Toda $v$ kontekstu izbranih romanov lahko govorimo o tem, da je oblačilna kultura postavljena $\mathrm{v}$ jaromeščanski ambient, zato da izpostavi poseben duhovni in kulturni utrip ne docela razvite sredine malega kraja Borje.

\section{Teoretska izhodišča}

Oblačila že sama po sebi govorijo s svojo simboliko. Predvidoma pa v Kersnikovih besedilih več kot te vrojene simbolike, ki je del »kolektivnega spomina ${ }^{3}$ in jo $\mathrm{v}$ dojemanje sveta nemalokrat vključujemo nezavedno, ne bomo našli. Lotman trdi, da simbol obstaja že pred literarnim tekstom in hkrati neodvisno od njega. Pisatelj ga v tekstu »oživi iz globin kulturnega spomina« in mu, vpletenemu v tekst, da nove razsežnosti (2006: 161), kar pomeni, da je »simbol posrednik med sinhronostjo teksta in kulturnim spominom «, lahko vstopa $\mathrm{v}$ nepričakovane povezave, pod vplivom katerih spreminja svoje prvotno bistvo, tisto »iz globin kulturnega spomina«, in nepričakovano, inovativno spreminja tekstno okolico (2006: 169).

Po pričakovanjih oblačila ne bodo prevzemala vlog literarnih simbolov. Kersnik je bil usmerjen $\mathrm{v}$ stvarnejše snovi, proti toku realizma, s pripovednimi tehnikami in značilnostmi, $\mathrm{v}$ katerih močnih simbolov ne moremo srečati. ${ }^{4}$ Glavni izrazni sredstvi, s pomočjo katerih Kersnik prikazuje notranje in zunanje položaje svoji oseb, sta opis in dvogovor (Paternu 1993: 44). Na oblačila, ki se $\mathrm{v}$ besedilih pojavljajo, bi morali torej pogledati kot na funkcionalne pred-

\footnotetext{
${ }^{2}$ Tudi način življenja ozke sredine je bil meščanski (posoda, aktivnosti v prostem času, bonton, posamezni luksuzni predmeti, pohištvo itd.). O tem piše Miran Štuhec v prispevku Trg - značilni ambient Kersnikovih romanov (1997: 60).

${ }^{3} \mathrm{O}$ kolektivnem spominu Lotman v delih Znotraj mislečih svetov (2006: 307-383) in Struktura umetniškega teksta (2010).

${ }^{4}$ Morda je izjema v romanu Ciklamen zgolj simbol ciklamna.
} 
mete. ${ }^{5}$ Smiselno je torej o njih spregovoriti kot o znakih. Pred tem je koristno najprej premisliti nekaj glavnih semiotičnih teorij, pri čemer imamo v mislih Barthesovo in Ecovo semiotiko. Postavljamo si vprašanje, kako začrtati mejo med oblačilom kot simbolom in oblačilom kot znakom. Vsak simbol je obenem tudi znak, a vsak znak še zdaleč ni simbol. Poizkusimo takole: če lahko oblačilo zadosti samo svoji prvotni funkciji, ki je pokrivanje telesa/zaščita, pomeni, da gre za znak. Če pa se nekje pojavi brez stvarne zveze z dogajanjem, ne odigra svoje primarne funkcije, njegova prisotnost pa je v svoji namembnosti nepojasnjena, nakazuje na psihološko ali duhovno vsebino/idejo, gre najverjetneje za znak z močnejšo simbolno vrednostjo, lahko gre za literarni simbol. Vendarle pa bomo težko prišli do trdnega sistema, v katerega bi lahko umestili čisto vsak pojav v čisto vsaki situaciji, saj ne smemo spregledati že prej omenjenega dejstva, da oblačila, v katerem ne bi bila že zapisana določena simbolna vrednost, ni. Toda ta simbolika ni predpogoj, da oblačilo ne bi moglo zadostiti svoji primarni funkciji in ne pomeni, da znotraj besedila oblačilo nujno deluje kot literarni simbol. Za prikaz vzemimo oblačilo, ki samo po sebi skriva simbolni pomen, ne glede na kontekst ali nositelja. ${ }^{6}$ Poročna obleka je bila v času romantike bele barve in je simbolizirala nevestino nedolžnost (O'Hara 1994: 188). ${ }^{7} \mathrm{~V}$ iste namene, prikazati nedolžnost in čistost nekega ženskega lika, bi poročno obleko kot tradicionalni (religijski) simbol lahko uporabil tudi pisatelj. Simbolika bi bila seveda razumljena, bralec bi jo brez težav razvozlal, saj se je njenega pomena skozi izkušnje »naučil«, a v besedilu ne bi odigrala vloge simbola. Elzina poročna obleka v Kersnikovem romanu Ciklamen ni literarni simbol. Lahko pa o njej govorimo kot o pričakovanem znaku v znakovnem sistemu, ki soustvarja sporočilo tradicionalnega obreda.

Roland Barthes se je intenzivno ukvarjal z znakovnimi polji privilegiranih sredin. ${ }^{8}$ Ena najbolj celovitih obravnav francoskega semiotika The fashion system obravnava jezik modnih časopisov, oblačila obravnava kot $\mathrm{z}$ besedami predstavljene predmete. Prav tako preučevanje je mogoče v literaturi. Po preučevanju so to izhodiščno še vedno jezikovni znaki, a njihova funkcija ni drugačna od funkcije, ki jo imajo ti isti znaki kot semiotični znaki. Barthes je znake predstavil kot družbeno konstruirane in človeku dostopne samo prek odnosov $\mathrm{z}$ drugimi ljudmi in zgolj v točno določenem družbeno-kulturnem kontekstu. Omenjeni pristop se pokriva $\mathrm{z}$ načeli mojega pristopa $\mathrm{k}$ obravnavi oblačil kot znakov v literaturi. Večina pojavov iz vsakdanjega življenja ima namreč svojo

\footnotetext{
${ }^{5} \mathrm{O}$ tem v nadaljevanju nanašajoč se na Eca in Barthesa.

${ }^{6}$ Zunaj besedila, je tradicionalni simbol.

${ }^{7}$ Ena sama upodobitev Brezmadežne device je imela daljnosežne posledice. Ko so cerkveni dostojanstveniki sredi 19. stoletja razglasili dogmo o brezmadežnem spočetju, so omejili tudi izbor figurativnih simbolov, ki so na primer spremljali srednjeveško in renesančno Brezmadežno. Z novo upodobitvijo Marije (belo oblačilo in pajčolan) /.../ so poudarili abstraktnost in nebeškost. Ta sprememba je vplivala na modo poročnih oblačil v 19. in 20. stoletju (Gombač 2011: 41).

${ }^{8}$ Semantična polja obleke, hrane, pohištva, arhitekture.
} 
pragmatično funkcijo. V drugačnem kontekstu pa lahko imajo sekundarne pomene, konotacije, ki so predmet Barthesovega zanimanja. Seveda konotacija ni zgolj nekaj individualnega, nekaj, kar posameznik neodvisno od okolja naredi iz pomena znaka. Konotativni pomeni nastanejo kot produkti kodov, do katerih imajo posamezniki dostop. Konotatorji so sestavljeni iz znakov denotacijskega sistema. Več denotacijskih znakov se lahko združi v en konotator. Kakorkoli konotacija preoblikuje, spreminja denotirano sporočilo, ga sama vendarle ne izčrpa: nekaj denotiranega vedno ostane (Barthes 1990b: 201-202). Za analizo je Barthesova semiotika uporabna zato, ker bom z njeno pomočjo opazovala, kako višji sloji preko modnega oblačenja vplivajo na nižje, ti na še nižje in tako dalje. Vsak sloj teži k posnemanju tistega, ki je bolj privilegiran, a Barthes trdi, da so luksuzne dobrine tudi sredstva manipulacije, sredstva, s katerimi lahko višji sloji dosegajo podrejenost in nemoč nižjih družbenih plasti.

Pomen znaka je »kulturna vsebnost«, torej je pomen vsakega znaka kulturno pogojen. Denotativni pomen semema je vsebina izraza, konotativni pomen semema pa vsebina funkcije znaka. Ali takole: denotativni pomen je v kulturi splošno prepoznana lastnost možnih referenc semema, konotativni pomen, ki ga nosi semem, pa ni nujno kulturno prepoznan kot eden »od možnih« (Eco 1979: 84-86).

\section{Kersnikova kritika nastajajočega slovenskega meščanstva}

Kersnik se je po romantičnih začetkih usmeril v sodobnejše snovi. V drugi polovici 19. stoletja se je posvetil svetu podeželskih izobražencev, ki ga je dobro poznal. Kersnik je eden redkih slovenskih pisateljev (vsaj do 20. stoletja), ki so izhajali iz izrazito premožnejšega okolja. Rodil se je na gradu Brdo pri Lukovici v ugledni slovenski intelektualni družini. Oče je bil sodnik, mati pa plemkinja, vnukinja graščaka dr. Burgerja ter solastnica gradu in veleposestva na Brdu. Kersnik je študiral na Dunaju in v Gradcu, kasneje pa kot pravnik delal v Ljubljani in na Brdu. Slovensko jaromeščanstvo je najbolj plastično prikazal v romanih Ciklamen (1883) in Agitator (1885). V obeh kritično obravnava navade in običaje nove gospode, ki že preko vedenjskih vzorcev in luksuznega predmetnega sveta ter posnemanja sveta meščanskih običajev odseva duhovno praznino, moralne pohabe, dvoličnost in prilagodljivost. Poleg ljubezenskih intrig se pojavlja kritika socialnega, kulturnega in moralnega položaja literarnih likov, ki so vedno postavljeni v enega od polov političnih teženj tedanjega časa. Skoraj refrensko se pojavlja tudi vprašanje slovenskega jezika in splošnega upora proti prevladujoči nemški kulturi (Pogačnik 1998: 32). Družbenozgodovinske razmere obdobja, v katerem sta nastajala obravnavana romana, so bile prelomne duhovno in politično. Rojevala se je zahteva po enakopravnosti narodov, dosežena je bila uvedba slovenščine $\mathrm{v}$ urade in šole. Prebujala so se slovenska mesta in trgi, s tem pa težnja po oblikovanju slovenske meščanske, trške kulture. 


\section{Habitus in oblačilna kultura}

Izhajajoč iz predhodno zapisanega je nujno osvetliti pojme meščanskost in meščanstvo, malomeščanstvo; opredeliti, kdo je meščan, ter v grobem preučiti ozadje meščanske kulture na Slovenskem. Ta je imela v svojem razvoju drugačno podobo kot meščanske strukture širšega evropskega prostora. Razvoj omenjene sredine z vsemi specifikami se zrcali tudi v literaturi. Meščanskost naj bi v prvi vrsti pomenila »kulturo«, nekakšen kulturno izoblikovan habitus, skupno prizadevanje določenega načina mišljenja in vedenja. ${ }^{9}$ Pojem habitusa kaže, da so kategorije mišljenja, umevanja, sheme zaznavanja, vrednostni sistemi ipd. proizvod vgrajenosti družbenih struktur (Bourdieu 201: 60). Meščanski habitus posreduje predstave o sebi in samozavest, ki jo definirajo posest materialnih dobrin, odnos do miselnih vrednot ter uporaba kulturnih vedenjskih vzorcev. Meščanska kultura se na zunaj izraža v svojih lastnih oblikah in normah, »kulturi« pa pripisuje dvojno funkcijo. Pojavlja se kot model identitete, pa tudi kakor sredstvo razlikovanja (Ovsec 2006: 129). Meščanstvo najprej predstavlja določeno formo, standarde, že zdavnaj potrjene vrednote, etiketo in hkrati notranji odnos do načina življenja: kaj se spodobi in kaj ne. Meščan je vsekakor človek takta, povezan je z bontonom, ki nikakor ne pomeni praznih vedenjskih vzorcev ali puhlic. V meščanskem svetu je po »pravilih igre« več ozirov in zavor, seveda pozitivnih, kot najrazličnejših svoboščin v poseganje življenja in delovanja drugih (Ovsec 2006: 131-132). Izraz malomeščanstvo je pejorativna oznaka za različne, ne natančno opredeljene načine mišljenja in življenja (Ovsec 2006: 128). Za Barthesa, čigar zanimanje je veljalo francoski buržoaziji in njeni kulturi, vedenjskim vzorcem, je problematična prav ta banalnost, s katero lahko posamezne skupine dosežejo nedotakljivost. Že zelo površni medosebni odnosi udeležene zaradi zunanjih pojavov umeščajo v posamezno družbeno skupino. Oblačilna kultura je bila v meščanskem okolju vedno posebej pomembna, bila je kot ustvarjena za uveljavljanje hierarhične delitve med posameznimi socialnimi sloji (Tomažič 2008: 171). Kot zapiše Bordieu, habitus poizkuša oblikovati »vsa razumska obnašanja«, ki so možna v okviru sprejetih zakonitosti znotraj določenega kroga, izloča pa vsa »čudaštva«, ker so po konceptu »to ni za nas« nezdružljiva z objektivnimi okoliščinami (2002: 95). Tudi moda ima svoj »prav« in svoj »narobe«. Principe, po katerih določa prvo oziroma drugo, pa uravnavajo tisti, ki do nje najlažje dostopajo.

V sredini 19. stoletja so slovenske pokrajine ohranjale različnosti v oblačilih in krojih. V ruralnem okolju so se spremembe uveljavljale počasneje kot v mestnem okolju. V tem času se je na Kranjskem razlil val prav posebnih dogodkov,

\footnotetext{
${ }^{9}$ Habitus je po Pierru Bourdieuju »izdelek zgodovine«, ki proizvaja »individualne in kolektivne prakse«. V njem so prisotne minule izkušnje, ki prisotne v vsakem organizmu v obliki »shem zaznavanja, mišljenja in praks« skušajo zagotoviti neformalno »pravilnost« in »nespremenljivost« praks. Ta nenapisana pravila družbenega vzorca in vedenja pa presegajo vsakršno normiranost, izhajajo iz preteklosti in se nadaljujejo v prihodnost (2002: 93).
} 
ki jih prej niso poznali. Na prireditvah, imenovanih bésede, ki so bile namenjene predvsem meščanski in trški gospodi, so se sestajali somišljeniki in v čitalnicah delili domoljubne ideje. Najbolj navdušeni so bili v meščanskih vrstah, ti meščani pa so bili zelo različnega porekla. Navsezadnje so bili tisti, ki so živeli v manjšem mestu ali trškem okolju, po stilu prebivanja, in seveda po premoženju, morda bolj meščanski kot manj premožni delavci v večjih mestih. Nenapisani družbeni zakoni so narekovali načine oblačenja. Če si je nekdo z obogatitvijo, z možitvijo ali ženitvijo pridobil nov socialni status, mu je bilo po prepričanju ljudstva dovoljeno spremeniti tudi stil oblačenja. Meščani so se zgledovali po dunajskih in praških trendih, šivilje in krojači pa po tujih modnih žurnalih. ${ }^{10}$ Odslužene obleke bogatih dam so velikokrat našle pot do domačih služkinj ali kuharic, ki so obleke nosile same ali jih odnesle domov, na kmete. Ohranjena gosposka obleka je bila dobrina, a na kmečki ženski ni smela biti vpadljiva (Tomažič 2008: 173-174). Oblačilna kultura na Slovenskem se je modernizirala skupaj s slovensko družbo. Moda je pravzaprav znanilka modernih družb. Njen razvoj oziroma že samo dejstvo, da ji posamezniki pripisujejo določeno vlogo $\mathrm{v}$ družabnih stikih, nakazuje premike v tradicionalnih družbah. ${ }^{11}$

\section{Oblačilni videzi moških literarnih likov}

\subsection{Roman Ciklamen}

Kersnik v romanu Ciklamen s paleto različnih oblačilnih videzov posmehljivo označi različne sloje ljudi, ki so se zbrali na poroki trškega graščaka:

/.../ gospodje so nosili vsi široke šope cvetlic v petlijicah ter opravljeni bili jako različno, kakor je tu v takih prilikah pač navada v naših malih mestih in trgih: poleg najnovejšega fraka videti je bila obnošena črna suknja nad rdečelisasto srajco, in sodnijski kancelist je tičal celo zaradi cestnega blata $\mathrm{v}$ visokih škornjih, pa nataknil si vendar bele rokavice (Kersnik 1993: 102).

10 »Okrajnega glavarja soproga in Boleška sta bili opravljeni po najnovejšem Bazaru« (Kersnik 1993: 102).

${ }^{11}$ Monografija Maje Gombač »Modni pêle mêle« slovenske družbe med svetovnima vojnama preučuje vlogo mode in modnega časopisja pri moderniziranju slovenske družbe v obdobju med svetovnima vojnama. Poudarek je na raziskovanju odnosa Slovencev do mode. Značilne naj bi bile karakteristike, kot so skromnost, sramežljivost ali previdnost. Mesto Ljubljana je še desetletja po času, v katerem sta nastala obravnavana romana Ciklamen in Agitator, namesto potez »tipičnega provincijalnega polkmečkega mesta« dobila bolj velemestni značaj. Uveljavljanje mode na slovenskem podeželju se je sicer začelo že v drugi polovici 19. stoletja, a se je proces hitrejšega širjenja mode poglobil v obdobju med svetovnima vojnama. $Z$ modernizacijo so se manjšale razlike med meščani, mestnimi prebivalci in kmeti, podeželani (2011: 331-338). 
Družbena struktura je bila $\mathrm{v}$ času nastanka romana povsem takšna, kakor jo opisuje Kersnik. Slovensko prebivalstvo se je začelo družbeno razslojevati. ${ }^{12}$

V Kersnikovih romanih je skupina, ki ustreza sloju nižjega uradništva, z oblačilnim videzom najbolj obremenjena, kar je Kersniku služilo kot odlično orodje za ustvarjanje jaromeščanskega ambienta, v katerega vpelje bralca že kar v prvem poglavju. Iz pogovora o oblačilih razberemo krčevito željo po pripadanju, težnjo po instantnem zadovoljevanju družbenih konvencij. Pogovor dveh povprečnežev o bližajoči se čitalniški prireditvi kot o velepomembnem dogodku omogoča spretno uvodno predstavitev preproščine (duhovne in tudi gmotne) podeželskega malomeščanskega sveta (Paternu 1993: 42). Izobrazbeni in premoženjski nivo višjih slojev sta za nepomembnega adjunkta Josipa Meglo nedosegljiva. Že po imenu neznaten uradnik pa je vendarle našel način, kako zadovoljiti primarno človeško potrebo po socialni opori, ki jo izpolnjeni oblačilni kodeks posamezniku omogoča. $Z$ oblačilom se je lahko postavil tudi pred tistim, ki mu je na socialni lestvici sicer enak: občinskim tajnikom Korenom, ki si je od njega moral izposoditi črne elegantne hlače. Opis priprave na čitalniško prireditev zavzema skoraj celotno prvo poglavje; označuje gospoda sodnega adjunkta ter obenem razkriva družbeno dogajalno ozadje in napoveduje prihodnji dogajalni tok.

Josip Megla se z ogledom pripravljene garderobe in obutve vsaj za silo potolaži zaradi svojega hripavega glasu, ki na prihajajoči prireditvi morda ne bo kos pevski nalogi. Pripravil si je popolnoma nove plesne čevlje; novo »deviško« črno suknjo; par masleno rumenih rokavic; bel, trd ovratnik; visok črn cilinder z neobičajno širokimi krajci. Opisani oblačilni videz je pravzaprav pomenil predpisano opravo meščanskih gospodov, a vendarle $\mathrm{v}$ malem trgu zavest $\mathrm{o}$ kodeksu oblačenja ni bila docela razvita, kar kaže na strukturo prebivalstva, ki je bila v osnovi kmečkega izvora, zelo se je razlikovala $\mathrm{v}$ izobrazbenem in ekonomskem smislu. Klobuk že v svoji osnovni simboliki deluje s pomenkami imenitnega. Cilindri so delovali gosposko, bili so obvezen del garderobe za svečane priložnosti v imenitni družbi. Po meščanskih cilindrih so se zgledovali tudi premožnejši kmetje v okolici mest in trgov (Žagar 2004: 117-118). Meglina ekstravaganca, ki je posiljena in komična, se pokaže že pri pokrivalu, saj je bil klobuk nad navadno mero širokokrajen. ${ }^{13}$ Koren se začudi dejstvu, da se bo Megla zabave udeležil s cilindrom na glavi. Potrditev svoje modne ozaveščenosti je Megla iskal tudi v pretiranem negodovanju nad izdelavo čevljev, ki jih je (tako kot klobuk) po stalni meščanski praksi naročil iz večjega mesta - v tem primeru Ljubljane. Megla se zgraža nad obliko čevljev, ki so po njegovem

${ }^{12}$ Slovenci so začeli zavzemati položaje in poklice, ki jih dotlej niso bili deležni. V kmečkem in obrtniškem ljudstvu je pričelo nastajati malomeščanstvo najskromnejše vrste, zbirali so se tenki sloji domačega razumništva, ki je prevzelo uradniške poklice (Vidmar 1976: 105).

${ }^{13}$ Dorfles piše, da so modni dodatki toliko močnejši statusni simbol, kolikor po nečem izrazito izstopajo (1997: 100). Hiperbolično pretiravanje je obenem tudi eden najpogostejših pojavov metaforičnega aspekta mode (Dorfles 1997: 145). 
mnenju preveč koničasti, s čimer zgolj hlasta po pozornosti, saj pripovedovalec pravi, da so mu všeč prav takšni čevlji, kakršne mu je napravil čevljar. ${ }^{14}$ Tudi Koren vljudnostno zagotovi, da so takšni čevlji zdaj pač moderni. Pogovor o čevljih se nadaljuje tako, da postaja namen Meglinega besedičenja nejasen. Zdi se, da želi upravičiti svojo nečimrnost in se deloma postaviti z novimi čevlji. Povsem jasno ni tudi to, zakaj bi se pretvarjal, da so mu čevlji preveliki. Majhnost stopala je namreč predvsem ženska »vrlina« in želja, nikakor ne moška. Pripovedovalec namreč zatrdi, da so Meglo čevlji pravzaprav tiščali. Da je treba za lepoto potrpeti, je znana stvar, morebiti je Megla samo želel dajati vtis, kot da mu prestižno obuvalo nikakor ni tesno in nenavadno, nosil ga bo z lahkoto, kot se za omikanega gospoda spodobi. Nehote se vsiljuje pravljična zgodba o Pepelki, katere nožica je bila edina dovolj krhka in gosposka, da je nosila elegantni čeveljc, njene robate sestre svojih stopal pa vanje niso spravile. In res se Meglina osebnost kaže nekoliko feminizirana, saj so trivialni pogovori o modi stereotipno ženska domena. Razkrije se tudi uradnikova labilnost, saj psihologija mode pravi, da ji sledijo prav tisti, ki sami nimajo dovolj poguma ali domišljije, da bi izstopali. Najzvestejši sledilci modnih zapovedi so pravzaprav dolgočasneži, ki v svetu samostojni ne znajo in ne zmorejo obstati. Tudi opis omenjenega potrjuje prav to povprečnost, na katero kaže že odnos do oblačil. Megla je povprečnega videza, okoren in neizobražen. Pri Kersniku so puhli pogovori o modi v moški pomenek umeščeni z veliko cinizma in posmeha, ki karikirata površinskost jaromeščanskih stikov in, kot poudarja pripovedovalec sam, govoričenja »brez jedra, brez duhovitega zrna«.

Omenjena okornost se kaže tudi v tem, kako Megla nosi gosposko obleko. Tako kot ne sodi v elegantne čevlje, tako se tudi njegova obleka ne prilega povsem. Frak mu smešno opleta okrog suhega telesa. Komično pri tem raste iz telesnih anomalij, ki jih obleka še poudarja. Nerodnosti kmečkega človeka ne more skriti niti čisto novi meščanski frak. Tudi tako občudovano pokrivalo, kot je cilinder, ni »naredilo človeka«, poveznilo se mu je namreč skoraj do ušes. Kršitev pregovornega frazema »obleka naredi človeka« deluje humorno in prehaja v milejšo ironijo. Davkarski adjunkt je tudi v oziru zgodbe popolnoma nepomembna in neugledna oseba. Otvoritveni prizor o bližajoči se pustni bésedi in dejstvo, da za pogovor o »kulturni« vsebini prireditve, ki jo morata Megla in Koren pomagati organizirati, porabita enako število besed kot za pogovor o tem, kaj bosta oblekla, pričata o duhovnem stanju in preproščini borjanskega nižjega uradništva.

O nehomogeni strukturi trškega prebivalstva priča tudi Korenova prošnja, ki jo ob koncu prvega poglavja naslovi na davkarskega adjunkta. Od njega si je želel izposoditi par črnih hlač, saj so njegove že čisto obnošene. Pri tem doda, da so rokavice še dobre, četudi pravzaprav nikomur ni mar za to. O zadnji pripombi bi glede na predhodno Meglino nastopaštvo z novo garderobo lahko nekoliko podvomili; a kmalu razumemo, da je Korenova pripomba iskrena in

${ }^{14}$ Čevlje povezujemo s seksualno simbologijo, tisti poudarjeno koničasti pa vsebujejo izrazito falusno konotacijo (Dorfles 1997: 149). 
tudi resnična. Večino gostov družabnih prireditev so še vedno predstavljali ljudje, ki jim za bele rokavice res ni bilo mar (z njimi je tudi težko jesti mastne perutninske kulinarične dobrote, ki so bile ključni del večernega druženja). Koren si hlače, četudi so »malo razparane«, od Megle sposoja ob vsaki bolj svečani prireditvi, kar opozarja na nedoseganje standardov primernega oblačilnega kodeksa. Prebivalci, katerih izkušnje dlje od domačega trga niso segle, na »meščanskost « prireditev niso bili pripravljeni. Prav posrečeno je tudi Meglino »maščevalno« vedenje, ko s Korenom pride v konflikt. Takoj namreč zahteva, da mu ta vrne hlače. Resnično, Meglino edino orožje so njegova oblačila.

\subsection{Roman Agitator}

V romanu Agitator je Kersnik stranskemu liku Andreju Korenu, ki ga iz Ciklamna poznamo kot neuspešnega študenta, nižjega uradnika, namenil eno glavnih vlog. Spremenjena, zresnjena družbena vloga - sedaj je odvetniški kandidat pri dr. Hrastu - se odraža tudi v njegovi zunanji drži:

Imel je sedaj blizu trideset let /.../ njegovi dolgi, nazaj česani lasje povzročevali so nekak resen vtis /.../ Tudi njegova vnanja oprava je bila sedaj elegantna, kakor se spodobi odvetniškemu kandidatu (Kersnik 1997: 12).

V oblačilnem oziru je eden od najvišjih trških dostojanstvenikov, okrajni sodnik Majaron, pravi upornik. Zaveda se, da ne zadosti merilom dostojnega oblačenja, da krši kodeks, da je soprogi zaradi tega nerodno, a hkrati ostaja zvest samemu sebi. Njegov značaj sicer ni pozitiven, saj so njegova dejanja politično oportunistično motivirana. Športna oprava na elegantni prireditvi pa vendarle kaže, da človek nikakor ni podoben Megli, temveč v sebi nosi nekaj provokativnega, sproščenega in samozavestnega, in da ni meglena sivina v množici, temveč nastopa $\mathrm{z}$ nekoliko osebnostne barvitosti. In res se tudi v komunikaciji z drugimi pokaže kot provokativen. Takšnega ga srečamo na večer famozne zabave - v debeli lovski suknji, s škornji čez kolena. Oblačilni videz, čeprav športno sproščen, se sodniku popolnoma prilega. Četudi s pripovedovalčeve perspektive ne zaznamo nikakršne kritike ali ironije - morebiti začutimo celo odtenek tihega odobravanja - gospa sodnikova obsoja moževo »robatost«: »Pipo bi bil tudi lahko doma pustil! In črno suknjo bi bil tudi lahko oblekel! In te škornje! Da se ne sramuješ’« (Kersnik 1997: 18). Sodnik se v svojem slogu za ženine pripombe seveda ne zmeni. Sodnikovega prilagajanja politični oblasti (ki je izrazito izraženo prav na dan bésede) Kersnik torej ne prikazuje tudi z oblačilnim videzom. Lovska oprava na čitalniški veselici pa nedvomno kaže na njegovo kmečko poreklo. Politično uklonljivost bi kasnejši Cankarjevi filistri, ki imajo povsem očitno korenine $\mathrm{v}$ Kersnikovih jaromeščanih, izkazovali že na zunaj, in sicer z zvestim posnemanjem gosposkega oblačilnega videza. Oblačila se pri Kersniku torej pokažejo v manj predvidljivih vlogah, predvsem pa ne v tako stereotipnih navezavah. Karikiranje je seveda prisotno, a ni tako 
izdelano, da bi bilo pričakovano. Tako ostaja sodnik v oblačilnem smislu do konca neuklonljiv. Na naslednji čitalniški slavnosti ga zopet srečamo kot enkrat poprej, $\mathrm{v}$ visokih škornjih in kratki lovski suknji.

Gospod Anton Meden, graščak iz Borja, je eden od premožnejših tržanov, oblečen je bil dokaj elegantno, pripovedovalec pravi skrbno; o naklonjenosti zlatnini pa je pričala debela zlata verižica pri uri in po več prstanov na vsaki roki. Edini od moških nosi nakit, kar govori o njegovi materialni moči. Pisatelj se pri Medenu posveti tudi detajlom fizičnega opisa (debeli vrat), ki v kombinaciji z izbrano garderobo ustvarjajo pomenske indice. Meden je v svoji osnovi čokat in kmečki. Četudi je z denarjem možno kupiti blišč, to ne velja tudi za okus. Prav nazoren dokaz slednjega najdemo v nekoliko zajedljivi pripombi v sledečih vrsticah:

Ta mož po svojem očetu, na pol kmetskem bogataši, ni bil drugega podedoval, nego denar, zato se tudi v vsem svojem življenji ni brigal za to, kar imenujejo izobraženi ljudje takt; kajti tudi tega je treba podedovati! (Kersnik 1993: 53).

Zasmeh torej raste iz nasprotja med fizičnimi determinantami in spremenljivko, ki je pogojena z denarjem - oblačili. Oboje ustvarja občutek »robate vzvišenosti« (Paternu 1993: 42). Tudi ko Meden k Boletovim pride z namenom ženitve, je skrbnost njegove zunanjosti posebej poudarjena, kar priča o ozaveščenosti nastajajočega meščanskega sloja o tem, kaj sodi k denarju, ugledu in priložnosti. Morebiti je prav tukaj prizadevanje za dosego tistega, kakor pravi Kersnik, takta: »Opravljen je bil najelegantneje; frak, beli ovratnik, cilinder in rokavice, vse je bilo novo « (Kersnik 1993: 35). S tem, ko v Agitatorju Medenova aroganca še nekoliko zraste, se razbohoti tudi njegova pojava; $v$ fraku, z rumenimi rokavicami, pokrit z visokim svilenim klakom pričakuje svoje goste. Debeli vrat mu sili izza ozkega, trdega ovratnika, ki poudarja njegovo robustnost - poročni blišč in z njim lepa Medenova oblačila Kersnik imenuje kar »blesteča oholost in kmetska baharija« (Kersnik 1993: 35). Pomenke debelosti v zahodnem svetu v zadnjih stoletjih že tradicionalno niso vezane samo na obilje, imajo tudi konotacijo požrešnosti. Ni naključje, da sta lastnosti še poudarjeni s pretesnim oblačilom. Če debeli vrat v Ciklamnu zmore uspešno skrivati z brado, se v Agitatorju bohoten del telesa razgali v vsej svoji obilnosti - tako kot se dokončno razkrije in okrepi tudi njegova nemškutarstvu naklonjena narava.

Poročni svatje, Medenovi gostje, so preko spretnega Kersnikovega opisa samo nekoliko zadostili merilom primernosti: »/.../ svatov pa je povabil, kolikor je znancev premogel, - da so le dolgo suknjo nosili« (Kersnik 1993: 101), saj se sorodnikov, ki so očitno razkrivali, kakšnega izvora je bogati ženin, ni mogel izogniti, »sorodniki njegovi so bili sploh skoro samo kmetje, - pa v cerkev jih ni pustil« (Kersnik 1993: 102).

Preostali pripadniki višjega trškega sloja so opisani kot elegantni in urejeni. Hrast, čeprav izhajajoč iz kmečke družine, je bil primernega oblačenja in vedenja že vešč, predstavljen kot »črno opravljen gospod, držeč v eni roki par 
belih rokavic, $v$ drugi pa stisnjen klak« zadosti vsem pravilom družabnega oblačilnega kodeksa: črna obleka (hlače, frak oziroma dolga suknja), bele rokavice (pojavlja se varianta masleno rumenih). Poleg obojega sem prištejemo še cilinder - v zgornjem opisu klak, pri čemer gre za zložljivi cilinder, ki ima ohišje iz žice, prevlečeno z blagom. Opis Hrastovega oblačilnega videza odraža zasebno uspešnost $-\mathrm{v}$ smislu poklicne poti in materialne preskrbljenosti. Je plast družabne konvencije, ki jo Hrast z željo, da ga drugi dojemajo kot zanesljivega in trdnega, vzdržuje brez posebnih vzgibov.

Pričakovano se oblačilnim videzom kmečkega prebivalstva Kersnik ni posvečal - razen $\mathrm{v}$ slikovitem primeru popisa svatov na Medenovi poroki, ko med povabljenci opazimo tudi sodnijskega kancelista v visokih škornjih, ki pa si je - popolnoma brez občutka za estetiko in manire - vseeno nataknil bele rokavice. Prav absurdna podoba opisanega vodi k zaključku, da večina tržanov pravzaprav ni vedela, kam in kako z belimi rokavicami ali drugimi meščanskimi predmeti in pojavi; pa naj gre za predavanje o astronomiji (Agitator) ali za prestižne alkoholne pijače. Rokavice so nosili, ker se jim je zdelo, da je tako prav, ne iz osebnega vzgiba in privzgojenega čuta za večkrat omenjeni »takt«, temveč iz golega posnemanja, ki je tudi njih umeščalo »nekam«, v tisto, po splošnem mnenju bolj privilegirano sredino.

V romanu Agitator se pojavlja še eno značilno modno znamenje aristokracije in blagostanja - kožuh oziroma krzno.

Kersnikov jaromeščanski gospod je predhodnik filistrov Ivana Cankarja, katerih karakterizacijo je omenjeni prignal do konca. ${ }^{15}$

Kersnik v največji meri opisuje oblačilne videze (malo)meščanskih gospodov. Podrobnejšega opisa moškega kmečkega oblačilnega videza ne zasledimo. Od oblačilnih kosov se najpogosteje pojavijo čevlji, hlače, klobuki, modni dodatki, kot so rokavice, nakit. So znaki družbene razslojenosti (glede na gmotno-intelektualne kapacitete), jaromeščanske nerazvitosti in ukleščenosti v banalne družbene konvencije, ki jim literarni liki niso dorasli. Oblačila označujejo družbeni status, njihovi opisi se spreminjajo skladno s spreminjanjem položaja na družbeni lestvici. Še pogosteje z njihovim opisovanjem Kersnik razlikuje pripadnike znotraj enake družbene sredine, kjer kriterij premoženja ne diferencira tako kot duhovna oziroma intelektualna vrlina pripadnika. Medrazredno in znotrajrazredno razlikovanje je $\mathrm{v}$ funkciji komičnega. Zunanje odstopanje od konvencij pa sugerira osebnostne lastnosti posameznikov (prilagajanje - četudi neuspešno, pomanjkanje lastnega jaza na eni in samovoljnost, okorelost $\mathrm{v}$ lastnih dogmah na drugi strani). Avtor z znotrajrazrednim razlikovanjem z oblačilnimi videzi pokaže, da pripadniki iste skupine ne delijo enakih vrednot (domoljubje,

${ }^{15}$ Filister je arhaizem za družbenega povzpetnika, puščobneža, hinavca, prilagodljivca in je eden osrednjih motivov Cankarjeve satirične proze. Na zunaj so to fini gospodje $\mathrm{v}$ dostojnih oblekah, s cilindri in z belimi rokavicami - izobražene »šeme v frakih» (Zadravec 1991: 112). V Kersnikovih romanih pa navadno tudi o oznaki »izobražen« ne moremo govoriti. 
miselna širina), gospodarsko elito loči od intelektualne. Neprilegajoča se, obnošena, premajhna oblačila se izrisujejo v komičnih prizorih, so v funkciji blažje ironije in karikature; v kombinaciji s telesnimi anomalijami (debelost, pretirana vitkost, neproporcionalnost telesa) pa delujejo groteskno. V kontrapoziciji z elitnim dogodkom, katerega neformalni del je primerna garderoba, poudarjajo nerazvitost meščanskega habitusa slovenskih pokrajin tistega časa.

\section{Sklep}

V Kersnikovih romanih jaromeščansko ali kmečko-malomestno socialno, duhovno in moralno okolje bralca postavi v vlogo opazovalca in moralno-etičnega razsodnika medosebnih odnosov ter odnosov do slovenstva in slovenskega skozi prikaz vloge premoženja in položaja v družbi (denar in kultura, kapitalistične ambicije novopečenih bogatašev, povzpetništvo); problematiko slovenskega etničnega obstoja (jezika, kulture); prikaz političnih razprtij (strankarski spopadi, predvolilni boji, želja po oblasti); odnose med spoloma (ljubezenski zapleti, tradicionalna vloga moškega in ženske v družbi in družini); prikaz stereotipov in predsodkov (pogosto vezanih na bipolarna razmerja urbano - ruralno, središčno - obrobno, domače - tuje, znano - neznano, izobraženo - neuko, bogato - revno). Našteto zrcali tudi z govorico oblačil in oblačilnih videzov. Ti kot znaki socialnega statusa kažejo na omenjene pojave. Prispevek oblačilne signale (pred)meščanskega, ki so povezani s prikazom prej opredeljenih medosebnih odnosov, splošnih človeških napak ter z univerzalnimi komičnimi situacijami, ki prehajajo $\mathrm{v}$ ironijo, umešča $\mathrm{v}$ meščansko oziroma malotrško stanovanje ali prireditveni prostor bésedo. Razmerje med videzom in resnico ustvarja komičnost, prostorsko in duhovno omejeni topos pa je ironiziran. Trdim, da so oblačila kot »druga koža« pravzaprav odraz posameznika (na zavedni ali nezavedni ravni) in $\mathrm{s}$ tem tudi socialne sredine, ki ji ta pripada - v rokah pisatelja so torej močno orodje karakterizacije, ki preko ustvarjanja garniture socialnih in socioloških odnosov nudi avtentično in izjemno dragoceno sliko stanja najsplošnejših družbenih pojavov veliko širšega značaja od modnih kapric. Romana Ciklamen in Agitator vsebujeta izrazite komponente specifičnega časa in družbe, kar odseva tudi preko oblačilnih videzov literarnih likov.

VIRA

Janko Kersnik, 1993: Ciklamen. Ljubljana: Karantanija.

- -, 1997: Agitator. Murska Sobota: Karantanija. 


\section{LITERATURA}

Roland BARTHES, 1990a: The fashion system. Berkeley: University of California Press. - -, 1990b: Retorika Starih, Elementi semiologije. Ljubljana: Studia humanitatis.

Pierre BOURDIEU, Roger CHARTIER, Carlo GINZBURG, 2011: Sociologija, zgodovina, književnost. Ljubljana: Studia humanitatis.

Jean CHEVALIER, Alain GHEERBRANT, 1993: Slovar simbolov. Ljubljana: Mladinska knjiga.

Jože DEŽMAN, Jože HUDALES in Božidar JEZERNIK (ur.), 2008: Slovensko meščanstvo: od vzpona nacije do nacionalizacije (1848-1948). Celovec: Mohorjeva družba.

Gilo DORFLES, 1997: Moda. Zagreb: Golden marketing.

Umberto ECO, 1979: A theory of semiotics. Bloomington: Indiana University Press.

- -, 1999: Šest sprehodov skozi pripovedne gozdove. Ljubljana: Labirinti.

--, 2005: O literaturi. Ljubljana: Učila.

Maja GOMBAČ, 2011: »Modni pêle mêle« slovenske družbe v obdobju med svetovnima vojnama. Ljubljana: Inštitut za novejšo zgodovino.

Jurij Mihajlovič LOTMAN, 2006: Znotraj mislečih svetov. Ljubljana: Studia Humanitatis.

- -, 2010: Struktura umetniškega teksta. Ljubljana: Literarni-umetniško društvo Literatura.

Georgina O'HARA, 1994: Enciklopedija mode: 1840-1990. Ljubljana: DZS.

Damjan J. OVSEC, 1991: Slovanska mitologija in verovanje. Ljubljana: Domus.

--, 2006: Nekaj o razvoju in pomenu meščanstva. Mesto in meščani v slovenskem jeziku, literaturi in kulturi. Ur. Irena Novak Popov. Ljubljana: Center za slovenščino kot drugi/ tuji jezik pri Oddelku za slovenistiko Filozofske fakultete. 124-134.

Boris PATERNU, 1993: Razpotja slovenske proze. Novo mesto: Dolenjska založba.

Jože POGAČNIK, 1998: Kersnikova Jara gospoda kot model slovenskega realizma. Janko Kersnik in njegov čas. Ur. Jan Zoltan. Ljubljana: Zavod Republike Slovenije za šolstvo. 23-34.

Miran ŠTUHEC, 1998: Trg - značilni ambient Kersnikovih romanov. Janko Kersnik in njegov čas. Ur. Jan Zoltan. Ljubljana: Zavod Republike Slovenije za šolstvo. 55-62.

Tanja TOMAŽIČ, 2008: Oblačila, »noša« in slovensko meščanstvo. Slovensko meščanstvo: od vzpona nacije do nacionalizacije (1848-1948). Ur. Jože Dežman, Jože Hudales in Božidar Jezernik. Celovec: Mohorjeva družba. 171-176.

Josip VIDMAR, 1976: O Ivanu Cankarju. Ljubljana: Mladinska knjiga.

Franc ZADRAVEC, 1991: Cankarjeva ironija. Ljubljana: Znanstveni inštitut Filozofske fakultete.

Janja ŽAGAR, 2004: Pokrivala: zbirka Slovenskega etnografskega muzeja. Ljubljana: Slovenski etnografski muzej. 
Irena ŽMUC, 2008: Slovensko meščanstvo ali iskanje žlahtnejših narodnih korenin. Slovensko meščanstvo: od vzpona nacije do nacionalizacije (1848-1948). Ur. Jože Dežman, Jože Hudales in Božidar Jezernik. Celovec: Mohorjeva družba. 67-79.

\section{THE ROLE OF MEN'S CLOTHING IN THE FAUX-BOURGEOIS AMBIENCE OF KERSNIK'S NOVELS CIKLAMEN AND AGITATOR}

In his description of clothing designs, Kersnik focuses on the male members of the petit bourgeoisie. In the novels in question, he pays no attention to the peasantry. The clothes of particular individuals vary according to their financial and intellectual capacities and indicate the underdevelopment of the petit bourgeoisie and its inability to perform social roles. Differences in clothing design suggest differences in the mental and intellectual virtues of the characters. The interclass and intraclass differentiation expressed through clothing is used in a comical function. The external deviations from the conventional or, conversely, the excessive desire to conform to it, suggest individual personality traits (adaptability and selflessness on the one hand and wilfulness and rigid adherence to one's own dogmas on the other). The small-town economic elite is distinguished from the intellectual elite through the description of clothing designs. Non-fitting, threadbare and undersized clothes are used in comedic scenes, often in combination with the description of physical anomalies, and convey mild irony and caricature. The article links the clothing designs of the (pre)-bourgeois, which are connected to the portrayal of interpersonal relationships between the inhabitants of the small town, to the exposing of basic human flaws and to the creation of comical scenes, in small-town apartments or the performance venue béseda. In the novels in question, Kersnik uses clothing to represent the underdevelopment of the bourgeois habitus of the Slovene provinces of the second half of the $19^{\text {th }}$ century. The novels Ciklamen and Agitator contain distinct components of a certain time and society, which are also expressed with the help of the clothing designs worn by the male characters. 